\title{
The Influence of Learning Model and Student Self-Concept Toward the Mathematical Problem-Solving Ability (Experimental Study on Students of Tangerang City State Junior High School)
}

\author{
Ruby Fauziyah Andam Dewi ${ }^{1}$, Anton Noornia ${ }^{2}$, Eti Dwi Wiraningsih ${ }^{3}$ \\ 1,2,3 Universitas Negeri Jakarta \\ Correspondence Address; fauziyahruby@yahoo.com
}

\begin{abstract}
This study aims to determine the effect of Conventional Model and the Missouri Mathematics Project (MMP) learning Model with self-concept on mathematical problem- solving abilities of junior high school students. The design of this study was experimental and control group posttest design. The method used is the quasi-experimental method using treatment by level $2 \times 2$ design. The experimental class was given the MMP learning model treatment while the control class was treated with conventional model. The samples of this study were 48 seventh grade students. The instruments used were self-concept questionnaires and a test of mathematical problem-solving abilities.Technique of analysis used was two-ways ANOVA. The results of this study show that the MMP learning model has a syntax that is able to empower mathematical problem-solving abilities compared to conventional learning model. Students who have a positive self-concept or students who have a negative self-concept are more suitable to be treated with the MMP learning model than conventional learning model.
\end{abstract}

Keywords: Abilities, Mathematical Problem-Solving, Self-Concept, Missouri Mathematics Project (MMP)

\section{INTRODUCTION}

Learning mathematics for students is still a scary and difficult lesson to study. This is because learning mathematics requires a process of critical thinking in solving the problems. Therefore, mathematics learning requires a precise strategy so that the students are able to solve problems in the learning context (Kemendikbud, 2017). Problem-solving is one of the focuses or objectives of learning mathematics (Herman, 2006). The learning process about how to solve problems will make students be more analytical critical in makingdecisions, consequently, it is important to be mastered.

Resolving non-routine questions requires students' involvement in mathematics learning. Learning is centered on students independently or in groups. The focus of learning moves from teacher to the student so students are able to develop their thinking ability to think creatively in solving problems. The statement above must be supported by a learning model. In this study,the learning model used is the Missouri Mathematics Project (MMP). The MMP learning model is a learning program designed in the form of training or project application. The aim is to develop independence and cooperation between groups. The application of the MMP model begins by inviting students to review their experiences, training them to solve problems in groups, and applying their learning outcomes independently. The steps in the implementation are introduction or review, development, exercises with teacher guidance, independent work, and conclusion (Shadiq, 2004). In other words, the MMP learning model is quite similar to practice.

The process of solving mathematical problems is closely related to the students' selfconcept. Self-concept is a condition of someone who understands themselves both physical, 
psychological, social, emotional, aspirations, and achievements. This self-concept is divided into two categories; they are positive and negative self-concept. The success of a student in achieving learning goals is inseparable from the self-concept they have (Komala, 2012) selfconcept includes the views, thoughts, actions or behaviors, and self-assessments.It can be concluded that self-concept is the ability of an individual to recognize oneself.

Based on previous research, several studies have been carried out in the use of the Missouri Mathematics Project (MMP) learning model in learning (Alba, Khotim, \& Junaedi, 2013; Kurniasari, Dwijanto, \& Soedjoko, 2014) and research in looking at problem solving abilities (Afryany \& Masrukan, 2015; Astriyani, 2016; E, S, \& Mashuri, 2015; Faelasofi, Arnidha, \& Istiani, 2015; Fitri, 2011; Imamah \& Toheri, 2014; Kusumawati, 2014; Laksana, Rochmad, \& Kharis, 2014; Mariya, Mastur, \& Pujiastuti, 2013; Muslim, 2017; Ngaeni \& Saefudin, 2017; Putra, 2017; Rahman, Hartini, \& An'nur, 2015; Ramadhani, 2017; Susanti, Musdi, \& Syarifuddin, 2017; Syazali, 2015; Yustianingsih, Syarifuddin, \& Yerizon, 2017). However, no research has been done that focus on the influence of theMissouri Mathematics Project learning modeland self-concept on the problem-solving ability. The purpose of this study is to determine the effect of theMissouri Mathematics Project (MMP) learning model, the conventional learning model, and self-concepts on students' mathematical problem-solving ability.

\section{THE RESEARCH METHODS}

The research method used in this study was quasi-experiment with the treatment by level $2 \times 2$ design, as shown in the following matrix;

Table 1. Design Research

\begin{tabular}{ccc}
\hline \multirow{2}{*}{ Self-concept $(B)$} & \multicolumn{2}{c}{ Learning Model (A) } \\
\cline { 2 - 3 } & Missouri Mathematics Project & $\begin{array}{c}\text { Conventional Learning Model } \\
(\mathrm{TTW})\left(\mathrm{A}_{2}\right)\end{array}$ \\
\hline Positive $\left(\mathrm{B}_{1}\right)$ & $\mathrm{A}_{1} \mathrm{~B}_{1}$ & $\mathrm{~A}_{2} \mathrm{~B}_{1}$ \\
Negative $\left(\mathrm{B}_{2}\right)$ & $\mathrm{A}_{1} \mathrm{~B}_{2}$ & $\mathrm{~A}_{2} \mathrm{~B}_{2}$ \\
\hline
\end{tabular}

The sampling technique used in this study was the multi-stage cluster random sampling technique. The target population in this study was all-state junior high school students in Tangerang City in the 2017/2018 academic year. The samples of this study were 48 students of the seventh grade. Data collection techniques employed were, first, the test of mathematical problem-solving ability instrument that had been validated by experts and had been empirically tested and calculated its reliability with the reliability coefficient of 0.808 . Second, the student's self-concept questionnaire that had been validated by experts and had been empirically tested of its reliability with the reliability score of 0.904 .

The technique used to analyze the data wastwo-ways variance analysis technique (ANAVA) at a significance level of $\alpha=0.05$. If an interaction is found in the analysis, then the test will proceed with the Tuckey Test. The normality test using Liliefors test was done before the result of the hypothetical test was analyzed.

The assumption of normality test is: 
$\mathrm{H}_{0:}$ The data is normally distributed

$\mathrm{H}_{1:}$ Data is not normally distributed

Test Criteria: If $\mathrm{L}_{\text {observed }}<L_{\text {table }}$ then $\mathrm{H}_{0}$ is accepted so that both data are normally distributed, while the homogeneity test used was theBartlett test with a confidence level of $\alpha=0.05$.

The assumptions for the homogeneity test are:

$\mathrm{H}_{0}$ : Homogeneous data

$\mathrm{H}_{1}$ : Data is not homogeneous.

Test Criteria: If $\mathrm{F}_{\text {observed }}<F_{\text {table }}$ then $\mathrm{H}_{0}$ is accepted, so that both data are homogeneous.

\section{THE RESULTS OF THE RESEARCH AND THE DISCUSSION}

The score of the mathematical problem-solving abilities between students who were treated using MMP learning model and the students who were treated using conventional learning model with different self-concepts can be seen in the following table:

Table 1. Descriptive Statistics Data Capability Mathematical Problem Solving Selfconcept

\begin{tabular}{|c|c|c|c|c|c|c|c|c|c|c|}
\hline \multirow[b]{2}{*}{$\begin{array}{c}\text { Self- } \\
\text { concept }\end{array}$} & \multirow[b]{2}{*}{ Score } & \multicolumn{5}{|c|}{ Missouri Mathematics Project (MMP) } & \multicolumn{4}{|c|}{ Convensional Model } \\
\hline & & $\begin{array}{c}\text { Number of } \\
\text { Students }\end{array}$ & Min & Max & Avarage & $\mathrm{SD}$ & $\begin{array}{c}\text { Number of } \\
\text { Students }\end{array}$ & Min & Max & Avarage SD \\
\hline Positive & Tes & 24 & 18 & 29 & 24,33 & 3,25 & 24 & 17 & 27 & $21,503,06$ \\
\hline Negative & Tes & 24 & 15 & 23 & 19,03 & 2,47 & 24 & 15 & 23 & $18,542,32$ \\
\hline Tota & & 48 & 15 & 29 & 21,68 & 3,90 & 48 & 15 & 27 & $20,023,07$ \\
\hline
\end{tabular}

Based on table 1, it can be seen that the results of the mathematical problem-solving abilitytests of students with negative self-concepts are more homogeneous than students with positive selfconcept. Based on the learning model used, it can be said that the results of the mathematical problem-solving abilitytest of students who were treated using the conventional model were more homogeneous than students treated with the MMP model. The average score of the mathematical problem-solving ability test has been presented to find out whether the MMP model has an effect and has a significant difference. On positive self-concepts for students who got the treatment of MMP learning model, the average score is greater than the conventional model and vice versa. This means that every student who has a different self-concept gives a different influence on the level of mathematical problem-solving ability. So, the factors of learning success are influenced not only by the use of learning models but also students' selfconcept in learning. Both of these factors become important and mutually integrated parts.

The results of the 2-ways analysis obtained the main effect on the mathematical problemsolving ability as follows.

Table 2.Mathematical Problem Solving Ability

Main Effect Sig




\begin{tabular}{lr}
\hline Model & 0,004 \\
Self-Concept & 0,000 \\
Models * Self Concept 0,048 \\
\hline
\end{tabular}

Table 2 is the result of the analysis of the influence of the main factors of the learning model which shows sig $=0.004$, which means that there are differences in mathematical problemsolving ability between students who got the treatment using MMP learning model with the students who got conventional learning model treatment. In accordance with the results in Table 1 , it can be concluded that the mathematical problem-solving ability of the students who were treated with the MMP learning model is higher than the students who got conventional learning model treatment. There is an effect of interaction between learning models and self-concept of problem-solving abilities as shown in Table 2 where the interaction effect of learning models with self-concept is sig $=0.048$. The higher the self-concept, the higher the results of the problem-solving skills possessed, especially the group of students who were treated with the MMP learning model. Students with positive self-concepts treated by the MMP learning model have higher problem-solving ability compared to students with positive self-concepts treated with conventional learning model.

The result of the treatment for each different treatment group using the Tukey test is shown in the following table.

Table 3. Mathematical Problem Solving Ability

\begin{tabular}{ll}
\hline Self-concept & Sig (2-tailed) \\
\hline Positive & 0,003 \\
Negative & 0,437 \\
\hline
\end{tabular}

Based on Table 3, the problem-solving ability of students in positive self-concept group is 0.0015.It can be concluded that there are differences in mathematical problem-solving ability between groups of students treated with MMP learning model with the conventional model on students who have a positive self-concept. based ontable 1, the average score of the mathematical problem-solving ability of students who were treated with the MMP learning model is higher than the mathematical problem-solving ability of students who were treated with the conventional modelon students who have a positive self-concept.

Based on Table 3, it is also known that the significance of the problem-solving ability of the students with negative self-concept is 0.2185 . It can be said that there is no difference in students' mathematical problem-solving abilities between groups of students treated with MMP learning model and conventional learning modelon students who have a low self-concept. The results of the fourth hypothesis data analysis showthat there is no difference in students' mathematical problem-solving ability between groups of students treated with MMP learning model and conventional learning model on students who have negative self-concepts. 
The results of the study showed that the mathematical problem-solving abilities between a group of students who received the MMP model treatment were higher than the group of students who were treated with conventional models. Learning with the MMP learning model begins with the teacher checking the attendance of students, conducting a review to remind students what they have learned before, and giving motivation to students. Next, the teacher divides students into several groups. The teacher provides opportunities for students to discuss within their groups while the teacher only acts as a facilitator who will direct students to answer the problems in the Student Worksheet during the discussion. Group discussions aim to make students have self-confidence and be open to other opinions. After students solve the problem given by the teacher, then the teacher gives an opportunity to one of the groups to present the answers. This activity trains students to be more confident to express their opinions. After students present their answers, the teacher and all the students will discuss the accuracy of the answers. Then the teacher and students will conclude what has been learned.

The explanation above illustrates that the MMP learning model applied in the classroom has an influence on students' mathematical problem-solving ability. Students are enabled to solve problems in groups so that they can discuss and provide solutions by stating the steps so that the students will understand more about the material.

In addition to the learning model, self-concept also has an influence on problem-solving ability. There isan interaction between the use of MMP learning model and conventional learning model on the mathematical problem-solving ability that depends on students' selfconcept. The MMP learning model is thought to be able to provide a better difference to students' self-concept when compared to a conventional learning model. The interaction shows that the groupshave a higher average mathematical problem-solving ability. The results of the study based on the testing of the third hypothesis show that students' mathematical problemsolving ability treated with MMP learning model on students who have a positive self-concept is higher compared to students who were treated with conventional model and have a positive self-concept. This happens because students who have a positive self-concept treated by the MMP learning model are able to develop mathematical problem-solving abilities. Burns states that self-concept is a regular process of self-perception. A high self-concept if supported by an MMP model that demands active students participation will makethem more aware of learning, knowing the purpose of learning, and determining their own strategies.

There is no significant difference in mathematical problem-solving abilities of students who have a negative self-concept if treated with MMP learning model or conventional learning model. Students with negative self-conceptwere more passive in class than students with positive self-concept. When group activities were held, students with negative self-concept did not express many opinions and appear to not understand the first step that must be taken when working on the problem. The teacher then assigned an individual assignment. The students with negative self-concept seemed to give up easily when they start working on the problem because they did not know the initial steps to do in working on the problem. This causes the 
mathematical problem-solving ability of students with negative self-concept does not experience a significant difference even though active learning has been applied.

The result of this study shows that teachers must have a creative concept in implementing the MMP learning model and the conventional learning model. This is because each student has a different self-concept. Although the students have the same self-concept, the way each student in learning is different. Apart from the self-concept factor, of course, the influence of the environment and the teacher in delivering the material has a great influence. This research finding provides a deeper understanding that the success of the student in learning is influenced by many factors such as teacher teaching strategies, psychological conditions while studying, parental support,and student learning facilities. The teacher has understood how to apply the discussion and the concept of cooperation in the MMP learning model or conventional learning model. Therefore, the results of this study also have the implication that the MMP learning model can be used as a model that can be applied to mathematics class. In addition, mathematics teachers can analyze how to find out the needs of students to achieve the goals of mathematics learning. The teacher has applied the MMP learning model to the mathematics class so that it has a real impact on improving learning abilities.

The Missouri Mathematics Project has an influence on mathematical connections and learning independence. This means that students' mathematical abilities would increase caused by independence and connectivity in learning. This has been proven in Yuliani's study that there is a relationship between MMP learning model and mathematical connection ability and students' independence in the algebraic calculation operation in the eight grade of SMP Negeri 2 Cilimus in the academic year of 2017/2018, Kuningan Regency. Student activities in the experimental class from the first meeting to the final meeting showed a significant increase. This is indicated by the percentage increase in each meeting with excellent criteria (Yuliani, Praja, \& Noto, 2018). So, MMP learning model has a significant influence on improving the ability to learn mathematics and the success in achieving learning goals (Widyawati, 2017). In addition, MMP can also be implemented using a problem-based learning approach. This can provide convenience to students while studying mathematics (Rahayu, Mariani, \& Masrukan, 2018). Different concepts have been studied that MMP has a high success rate through the concept of collaborative learning (Novalia, Makmuri, \& Sudrajat, 2018).

Connectivity and independence of learning become important in students' self-concept. Therefore, this research is more directed at the implementation of students' self-concept through MMP learning model and conventional learning model through collaboration between students since not all students have high abilities during the learning process. This is the difference between this research and previous research. So far, the application of the MMP learning model was only tested to determine the level of influence on the ability to learn mathematics. The similarity with this study is thatthe overall research is trying to provide a way for students to have the ability to solve difficult mathematical questions. This is applied to groups of students who have different self-concepts. This success has been demonstrated in the research by (Jafari Koshkouei, Shahvarani, Behzadi, \& Rostamy-Malkhalifeh, 2016). although their research is 
more focused on the mathematics self-concept, motivation, and self-regulation during learning towards academic achievement. The self-concept of mathematics influences the motivation to learn mathematics and motivation to learn mathematics influences self-regulation learning. Compared to the motivation to learn mathematics and self-regulating learning, the self-concept of mathematics is a stronger predictor of mathematics academic achievement. So, the difference in this research is indicated by the application of MMP learning model and conventional learning model through peer learning when discussions are conducted.

\section{CONCLUSION AND SUGGESTION}

The results of data analysis concluded that the MMP learning model has a significant influence on the mathematical problem-solving ability for students who have a positive selfconcept. This is the same as the group that gets treated with the conventional learning model. The group of students who have negative self-concept does not have differences in mathematical problem-solving abilities both taught using MMP learning model and conventional learning model. This means that the use of learning models has a different level of diversity depending on the self-concept of each student. The students who have a positive self-concept show good attitudes and behaviors towards the learning motivation and the desire to succeed because they are able to face every weakness they have towards the implementation of learning. So that the application of both MMP learning model and the conventional learning model has challenged students to improve their mathematical problem-solving ability.The students who have a low self-concept have difficulties in managing their strengths and weaknesses.

The study proposes several suggestions. The learning process becomes more qualified with the use of learning media or the use of technology. Further research is expected to be able to study a wider range of issues for the development of science in the research world by using other learning models to maximize problem-solving ability.

\section{REFERENCE}

Afryany, L., \& Masrukan. (2015). Pembelajaran DSCI Dengan Asesmen Polya Untuk Meningkatkan Kemampuan Pemecahan Masalah Siswa Kelas VIII Materi Lingkaran. Unnes Journal of Mathematics Education, 4(1), 15-21.

Alba, F. M., Khotim, M., \& Junaedi, I. (2013). Keefektifan Model Pembelajaran Generatif dan MMP Terhadap Kemmpuan Pemecahan Masalah. Kreano: Jurnal Matematika KreatifInovatif, 4(2), 131-137.

Astriyani, A. (2016). Peningkatan Kemampuan Pemecahan Masalah Peserta Didik Dengan Penerapan Model Pembelajaran Problem Posing. Fibonacci: Jurnal Pendidikan Matematika Dan Matematika, 2(1), 23-30.

E, S., S, M., \& Mashuri. (2015). Studi Perbedaan Keefektifan Pembelajaran LC-5E dan CIRC Terhadap Kemampuan Pemecahan Masalah Matematika. Jurnal Matematika Kreatif Inovatif, 6(1), 26-32. 
Faelasofi, R., Arnidha, Y., \& Istiani, A. (2015). Metode Pembelajaran Mind Mapping untuk Meningkatkan Kemampuan Komunikasi Matematik Siswa Dalam Pemecahan Masalah Matematika. Jurnal E-DuMath, 1(2), 122-137.

Fitri, A. (2011). Pengembangan Perangkat Pembelajaran Statistika Dasar Bermuatan Pendidikan Karakter Dengan Metode Problem Based Learning. Jurnal PP, 1(2), 159-165.

Herman. (2006). Strategi Pemecahan Masalah (Problem Solving) dalam Pembelajaran Matematika. Bandung: Universitas Pendidikan Indonesia.

Imamah, F. U., \& Toheri. (2014). Pengaruh Penggunaan Kombinasi Metode Pembelajaran Discovery Learning Dan Brain Storming Terhadap Kemampuan Pemecahan Masalah Pada Pokok Bahasan Himpunan. EduMa, 3(1), 120-137.

Jafari Koshkouei, H., Shahvarani, A., Behzadi, M. H., \& Rostamy-Malkhalifeh, M. (2016). Structural Modeling for Influence of Mathematics Self-Concept, Motivation to Learn Mathematics and Self-Regulation Learning on Mathematics Academic Achievement. Mathematics Education Trends and Research, 2016(1), 1-12.

Kemendikbud. (2017). Kurikulum 2013 Edisi Revisi. Jakarta: Kementrian Pendidikan dan Kebudayaan.

Komala, E. (2012). Pembelajaran dengan Pendekatan Diskursif untuk Meningkatkan Kemampuan Pemecahan Masalah Matematis dan Self-Concept Siswa Sekolah Menengah Pertama. Tesis Pada SPS UPI. Tidak Dipublikasikan.

Kurniasari, I., Dwijanto, \& Soedjoko, E. (2014). Keefektifan Model Pembelajaran MMP Dengan Langkah Pemecahan Masalah Polya Terhadap Kemampuan Berpikir Kreatif Siswa. Unnes Journal of Mathematics Education, 3(2), 1-6.

Kusumawati, S. W. (2014). Penerapan Model Pembelajaran SAVI Untuk Meningkatkan Keterampilan Pemecahan Masalah di Sekolah Dasar. JPGSD, 2(2), 1-10.

Laksana, R. A. T., Rochmad, \& Kharis, M. (2014). Keefektifan Model Pembelajaran STAD Disertai Permainan MAM Terhadap Kemampuan Pemecahan Masalah Kelas X Materi Logaritma. Unnes Journal of Mathematics Education, 3(2), 126-131.

Mariya, D., Mastur, Z., \& Pujiastuti, E. (2013). Keefektifan Pembelajaran SAVI Berbantuan Alat Peraga Terhadap Kemampuan Pemecahan Masalah. Unnes Journal of Mathematics Education, 2(2), 41-47.

Muslim, S. R. (2017). Pengaruh Penggunaan Model Project Based Learning Terhadap Kemampuan Pemecahan Masalah Matematis Peserta Didik SMA. Supremum Journal of Mathematics Education (SJME), 1(2), 88-95.

Ngaeni, E. N., \& Saefudin, A. A. (2017). Menciptakan Pembelajaran Matematika yang Efektif Dalam Pemecahan Masalah Matematika Dengan Model pembelajaran Problem Posing. Jurnal Aksioma, 6(2), 264-274.

Novalia, R., Makmuri, M., \& Sudrajat, A. (2018). Application of Type Cooperative Learning 
Models Missouri Mathematics Project (Mmp) to Increase Learning Results Math. American Journal of Educational Research, 6(8), 1085-1092. https://doi.org/10.12691/education-6-8-4

Putra, F. G. (2017). Eksperimentasi Pendekatan Kontekstual Berbantuan Hands On Activity (HoA) Terhadap Kemampuan Pemecahan Masalah Matematik. Al-Jabar: Jurnal Pendidikan Matematika, 8(1), 73-80.

Rahayu, Y. K., Mariani, S., \& Masrukan, M. (2018). Journal of primary education. Journal of Primary Education (Vol. 8).

Rahman, A., Hartini, S., \& An'nur, S. (2015). Perbedaan Keterampilan Pemecahan Masalah Pada Pembelajaran Fisika Menggunakan Metode Problem Posing dan Problem Solving. Berkala Ilmiah Pendidikan Fisika, 3(1), 44-51.

Ramadhani, R. (2017). Kemampuan Pemecahan Masalah Matematika Siswa SMA Melalui Guided Discovery Learning Berbantuan Autograph. JPPM, 10(2), 72-81.

Shadiq, F. (2004). Pemecahan Masalah, Penalaran, dan Komunikasi. Yogyakarta: Departemen Pendidikan Nasional.

Susanti, Musdi, E., \& Syarifuddin, H. (2017). Pengembangan Perangkat Pembelajaran Matematika Materi Statistik Berbasis Penemuan Terbimbing Untuk Meningkatkan Kemampuan Pemecahan Masalah Matematis Materi Statistika. Jurnal JNPM ( Jurnal Nasional Pendidikan Matematika ), 1(2), 305-319.

Syazali, M. (2015). Pengaruh Model Pembelajaran Creative Problem Solving Berbantuan Maple II Terhadap Kemampuan Pemecahan Masalah Matematis. Al-Jabar, 6(1), 91-98.

Widyawati, N. (2017). Applying Missouri Mathematics Project Model in Enhancing Math Learning Outcomes. International Journal of Managerial Studies and Research (IJMSR), 5(1), 15-18.

Yuliani, R., Praja, E. S., \& Noto, M. S. (2018). Pengaruh Model Pembelajaran Missouri Mathematics Project Terhadap Kemampuan Koneksi Matematis dan Kemandirian Belajar Siswa SMP. Jurnal Elemen, 4(2), 131.

Yustianingsih, R., Syarifuddin, H., \& Yerizon. (2017). Pengembangan Perangkat Pembelajaran Matematika Berbasis Problem Based Learning (Pbl) Untuk Meningkatkan Kemampuan Pemecahan Masalah Peserta Didik Kelas VII. Jurnal JNPM (Jurnal Nasional Pendidikan Matematika ), 1(2), 258-274. 